\title{
ETNOGRAFIA DA GALERA DO CAPRICHOSO SIMBOLISMO E SOCIABILIDADE ENTRE JOVENS NO FESTIVAL DE PARINTINS
}

Ricardo José Barbieri (UFRJ)

O Festival de Parintins pode ser observado sob diversos aspectos dada a multiplicidade dos planos simbólicos que orientam a festa. Um dos principais mecanismos de articulação desses planos simbólicos se constitui das pessoas que se movimentam e incentivam seus bois em performances coreografadas nas arquibancadas - a chamada galera dos bois, importantíssima no julgamento do festival. Aqui a galera do Boi Caprichoso é tomada como ponto de partida para percorrermos os circuitos articulados por integrantes desse grupo ao longo dos ensaios e mobilizações diversas em Parintins e Manaus.

FESTIVAL DE PARINTINS; BOI-BUMBÁ; SOCIABILIDADE.

BARBIERI, Ricardo José. Etnografia da galera do Caprichoso: simbolismo e sociabilidade entre jovens no festival de Parintins. Textos escolhidos de cultura e arte populares, Rio de Janeiro, v.10, n.1, p. 63-80, mai. 2013. 


\section{AN ETHNOGRAPHY OF THE GALERA DO CAPRICHOSO}

SYMBOLISM AND SOCIABILITY AMONG YOUTH

IN THE PARINTINS FESTIVAL

Ricardo José Barbieri (UFRJ)

The Parintins Festival can be regarded in several aspects given the multiplicity of symbolic plans that per pass the party. One of the main mechanisms in the symbolic articulation of these plans is composed by the people who engage and encourage their ox in choreographed performances from the bleachers - the so-called ox crowd, an important part in the judging of the festival. In this article the Caprichoso Ox crowd is taken as a starting point through the circuits articulated by members of this group over the various rehearsals and demonstrations in Parintins and Manaus.

PARINTINS FESTIVAL; BOI BUMBA; SOCIABILITY.

BARBIERI, Ricardo José. Etnografia da galera do Caprichoso: simbolismo e sociabilidade entre jovens no festival de Parintins. Textos escolhidos de cultura e arte populares, Rio de Janeiro, v.10, n.1, p. 63-80, mai. 2013. 


\section{INTRODUÇÃO: A PREPARAÇÃO PARA A VIAGEM}

Viajar para Parintins foi a primeira experiência de distanciamento pleno que vivi. Antes meu horizonte se limitava a observar minha cidade, tudo que a cerca e como se movimenta num contexto bastante familiar para mim, o do carnaval carioca e das escolas de samba. No fim de mais um dia de pesquisa voltava para o conforto de minha cama, de minha casa. Foram 15 dias de distanciamento nunca antes experimentado. O Estado do Amazonas, a cidade de Parintins e sua festa representavam exotismo inédito. Meu contato com a festa até então consistia em alguns documentários e artigos, e visualização, durante dois anos, de alguns trechos transmitidos pela televisão.

\section{O item "galera"}

Assim fui pesquisar a galera do Boi Caprichoso. Atualmente são 22 os itens em julgamento na competição do Festival Folclórico de Parintins. Um dos mais disputados é o de melhor "galera", considerado, aliás, relevante a ponto de todos os anos o principal jornal do Amazonas, $A$ Crítica, ressaltar o vencedor do item na planilha após a apuração das notas.

O julgamento em cada noite é efetuado por 12 jurados específicos, que julgam de acordo com sua especificidade (musical, artístico, cênico/coreográfico). A nota mínima de cada item é sete, e a máxima, dez, podendo ser fracionada na forma decimal e devendo ser lançada na folha de votação, numericamente e por extenso. Sobre o item "Galera" o artigo 39 do regulamento do Festival Folclórico estabelece os seguintes critérios, que os jurados devem considerar na votação:

DEFINIÇÃO: Elemento de apoio do espetáculo, estímulo de apresentação, massa humana que forma uma das maiores coreografias uníssonas do mundo.

MÉRITOS: Alegria, energia contagiante, sincronia, garra, evolução e empolgação.

ELEMENTOS COMPARATIVOS: Animação, alegria, calor humano, participação e sincronia (Anteprojeto do regulamento do XXXVIII Festival Folclórico de Parintins 2003. Regulamento do concurso de bumbas).

Entre as principais características desse item estão a polêmica e as paixões despertadas em torno dele. Por seu julgamento extremamente subjetivo e pela passionalidade nele representada, esse item é objeto de contestação de muitos torcedores. Simultaneamente é elemento de distinção do Festival por denotar seu caráter participativo (Figura 1). 


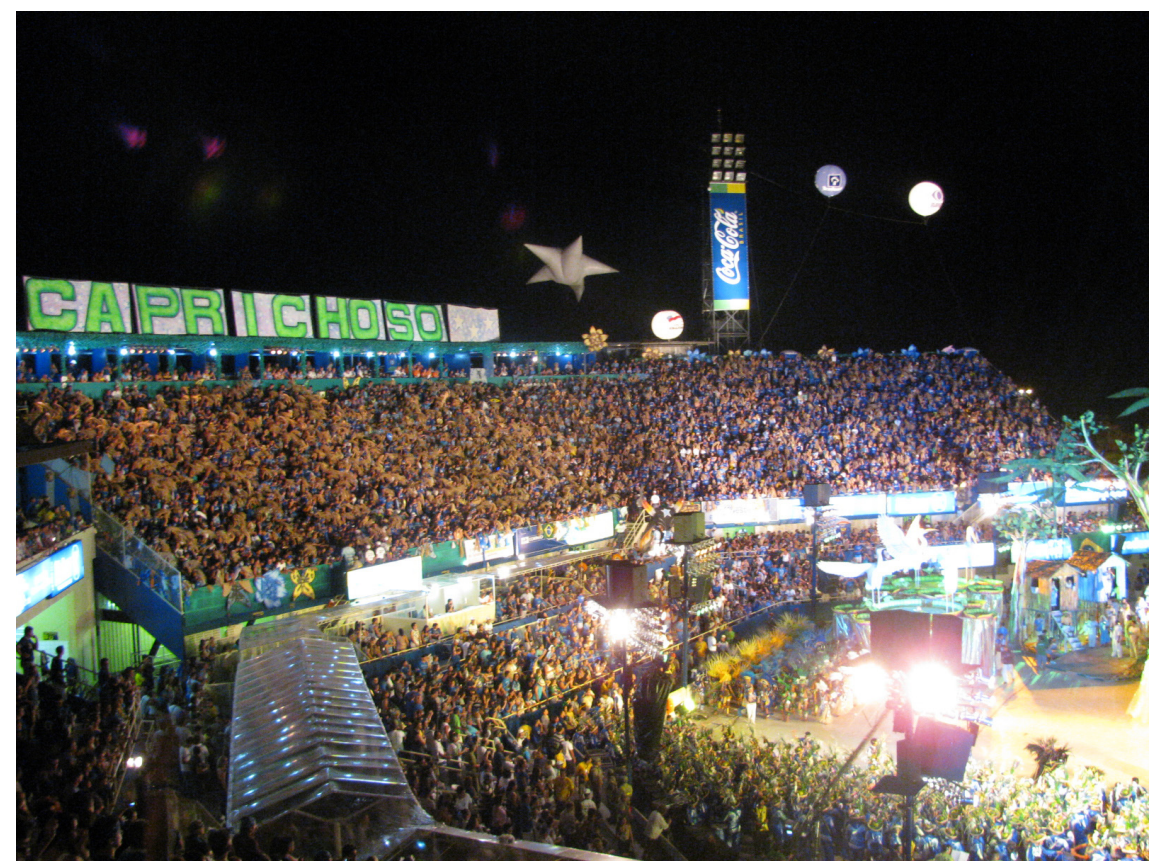

Figura 1: Galera do Caprichoso durante apresentação 2010 Foto do autor

Apesar de o termo galera ser importado das galeras funk cariocas (CECHETTo, 1997), o tipo de sociabilidade característico das galeras dos bois de Parintins difere em muito do mundo funk carioca. A começar por seu tipo de organização, que remete muito mais ao das torcidas organizadas. Assim como as torcidas organizadas, as galeras de Parintins são "organizações heterogêneas agregando indivíduos com diferenças de idade, classe social, profissão e visão de mundo" (CÂMARA, 2000). Essas organizações, entretanto, identificam-se mais com jovens entre 13 e 25 anos, que compõem sua maior parte.

Estudar a galera do Boi Caprichoso seria, portanto, estudar os jovens que dela fazem parte e são sua maioria. Meu principal contato no local seria Gean, 20 anos, apresentado por Alessandro, webmaster da página do Boi Caprichoso (www.boicaprichoso.com.br), como coreógrafo da galera. Eu entrara em um fórum do site, onde os mais variados assuntos são discutidos, e recebi poucas horas depois um e-mail do webmaster Alessandro com o endereço eletrônico e o telefone de Gean. No dia seguinte, o próprio Gean fez contato. Foi muito solícito por e-mail e por MSN. Mesmo assim conversamos pouco, mas ele adiantou muitas coisas que me esperavam em Parintins. Um dia antes de viajar telefonei para ele a fim de acertarmos um possível encontro, que acabou não acontecendo em 
Manaus. Nesse primeiro contato ele já pareceu bem mais à vontade. Nessa ligação além de combinarmos o primeiro encontro falamos um pouco sobre a relação dele com a galera do Caprichoso. Segundo seu relato, Gean começou a trabaIhar com a galera aos 17 anos, mas torce para o Caprichoso desde os nove anos de idade, por influência de sua mãe, que "sempre foi Caprichosa".

\section{Sorteio dos estados dos julgadores: começa a competição}

O sorteio dos estados de origem dos jurados foi meu primeiro contato de fato com o Festival, ainda em Manaus. Ali as dicotomias já são encenadas, e a rivalidade se faz presente. Os representantes de cada boi fazem questão de trajar as cores do seu e sentar-se em lados opostos. O clima é de tensão e ansiedade, embora travestidas em sorrisos amarelos de uns e outros. Até mesmo entre os funcionários do governo a tensão é latente. De fato, tudo é disputado na festa, até quem será o primeiro a vetar um estado sorteado, disputa por meio de um par ou ímpar e vencida pelo representante do Garantido. Na presença do secretário estadual de Cultura, de funcionários da secretaria e da imprensa, foram sorteados os estados do Ceará, Tocantins, Rio de Janeiro, Rio Grande do Sul e Piauí. O Garantido vetou o estado do Ceará, e o Caprichoso, o Piauí. A seguir o estado do Tocantins foi sorteado para ter o presidente do júri, ou seja, mandar um representante a mais, completando quatro jurados. Todos parecem ter saído satisfeitos e otimistas com os estados escolhidos. A partir daquele momento os bois enviariam um representante de cada para cada um dos estados sorteados, onde escolheriam de forma consensual os jurados e os convenceriam a participar do Festival que aconteceria em uma semana. Isso envolve a articulação de tão grande e intensa rede de interesses, que abarca estudiosos de folclore e cultura popular, dramaturgos, bailarinos, músicos e artistas com potencial para julgamento do Festival. Os dois bois mobilizam pessoas influentes entre seus simpatizantes nos estados escolhidos para formação do júri especulando seu interesse a partir do momento em que são anunciados.

\section{Eventos dos bois em Manaus}

Já naquela segunda noite em Manaus pude conhecer os eventos dos bois, nesse caso o Garantido. Os ensaios do Garantido na cidade são realizados atualmente no sambódromo, organizados pelo Movimento Amigos do Garantido MAG, e os do Caprichoso, no mesmo local, organizados pelo Movimento Marujada. A trajetória e o desenvolvimento desses eventos e sua mobilização junto aos moradores de Manaus explicitam sua forte ligação com o Festival Folclórico de Parintins. O formato do sambódromo de Manaus inclui área circular em que, nos 
desfiles, acontece a dispersão dos grupos e, fora deles, são realizados esses ensaios com a instalação de um palco na pista, fechando totalmente o círculo.

Nos ensaios geralmente se apresenta um grupo musical que canta toadas ligadas a cada um dos bois, antigos levantadores de toadas e jovens promessas que em alguns casos fazem parte do grupo vocal de arena. Assisti a apenas um ensaio, o último do Garantido em Manaus. Nesse caso o levantador de toadas oficial vinha sendo poupado pois passava por uma série de complicações de saúde. Assim, ele não se apresentou no evento do Garantido em Manaus; uma parte da batucada do Garantido, composta por moradores de Manaus, cuidou da animação em seu lugar e constituiu o ápice da apresentação. O evento chamado Curral do Garantido ${ }^{1}$ é realizado no sambódromo e compreende todo o ciclo de preparação dos bois, configurando-se como importante veículo de publicidade. Basicamente é evento de divulgação e arrecadação, no qual as coreografias e a música são atrações. As coreografias apresentadas no palco são bem mais complexas que as executadas no Festival. Um bom público ocupava a parte final do monumental sambódromo de Manaus, uma construção circular que quando ocupada pelo palco central tem traços característico de uma arena a céu aberto. Nas arquibancadas vazias que circundam a arena improvisada com a montagem do palco para os shows, um enorme bandeirão da facção que organiza a galera do Garantido, o Comando Garantido, foi aberto. Na ocasião, entretanto, vi poucas camisas da galera em comparação com o número de camisas da Batucada e do MAG. Chamou atenção nesse evento a presença de um jovem com camisa do Caprichoso que dançava as coreografias das músicas animadamente.

\section{Desembarque em Parintins}

No dia seguinte aconteceu o tão esperado embarque para Parintins. A viagem de avião Manaus-Parintins é curta, nem um pouco cansativa. No aeroporto encontramos algumas personalidades, como o apresentador e a sinhazinha do Caprichoso, e o famoso varejista de artigos carnavalescos Chiquinho do Babadão.

Excetuando-se o monumental bumbódromo, a cidade é simples, e ficamos hospedados em seu lado azul, um pouco distante do aeroporto. Por esse percurso, ainda que menor do que o correspondente em Manaus, nos foi cobrado valor igual: 40 reais. A casa em que ficamos é excelente em relação aos padrões da cidade, cujas famílias no período do Festival, quando se estima que duplique o tamanho da população, costumam alugar casas simples ou apenas quartos aos visitantes. As almofadas nas cores azul e branca demarcam território: é uma casa caprichosa. Os detalhes são impressionantes. Da janela de meu quar- 
to é possível ver a bandeira do curral do Caprichoso tremular, uma imagem marcante e inspiradora.

À tarde encontramos Gean, um dos coreógrafos de uma facção da galera, a FAB - atualmente no Boi Caprichoso são duas as organizações que coordenam a galera, como núcleos centrais: a Raça Azul e a Força Azul e Branca, conhecida pela sigla FAB. A formação desses dois grupos mostra seu dinamismo e até determinada autonomia em relação ao funcionamento institucional do boi. Na administração do Boi Caprichoso vigente em 2010, o presidente Carmona tentou unificar as facções criando a Raça Azul. A Força Bravura Independente (FBI) aderiu à nova organização e se diluiu oficialmente. A FAB inicialmente também aderiu à nova torcida, mas continuou existindo organicamente e separou-se novamente em 2009. Em 2010 seus torcedores e núcleos foram cadastrados nas cidades de Manaus, Parintins, Terra Santa, Itacoatiara, Maués, Barreirinhas e Rio de Janeiro (o único núcleo fora do Estado do Amazonas). Apesar da organização, nenhum membro sabe precisar o número de filiados; visualmente, entretanto, pode-se estimar, tanto pela quantidade de torcedores uniformizados pelas ruas de Parintins quanto por sua presença uniformizada nas arquibancadas nos eventos do Festival, que seja a maior facção da galera do Caprichoso. A Raça Azul, por sua vez, tem núcleos em Parintins e Manaus. No último Festival despontou como núcleo a "comunidade do Caprichoso" no Orkut (a principal rede social da internet), ainda que sem organização formal e de menor presença na arquibancada Seus membros, entretanto, são convocados a participar das reuniões de distribuição dos efeitos e adereços nas arquibancadas durante as apresentações no festival.

Voltando ao encontro com Gean em Parintins, ele nos recebeu com Taynah, moça extremamente simpática e fanática pelo Caprichoso. Apesar de meu contato inicial com Gean, foi Taynah quem cooptou nossas atenções no caminho para a casa em que assistiríamos ao jogo da seleção pela Copa do Mundo - uma oportunidade maravilhosa para conhecer aquele grupo tão ligado ao Caprichoso, até porque falamos horas sobre o assunto predileto deles: o Boi Caprichoso. As derrotas injustas, as grandes vitórias, os momentos marcantes, os trágicos incidentes tudo isso em um discurso cuidadosamente construído para enaltecer o capricho e a dedicação de seu boi. Dedicação que torna os papéis dos brincantes fluídos e norteados pela pergunta "onde posso ser útil ao boi?" Um deles, aliás, utilizou essa frase ao explicar-nos, em 19.6.2010, sua opção por comprar cadeiras e não ficar nas arquibancadas gratuitas da galera:

Já fiz de tudo no boi. Participei do corpo de dançarinos na arena, já fui da galera... Ano passado estava na galera, mas estou cansado. Ano passado tive que ficar jogando lata e empurrando quem fica- 
va parado, saí de lá irritado e cansado. Este ano vou para a cadeira onde posso ficar mais tranquilo".

\section{As facções da galera do Caprichoso}

A seguir fomos ao bumbódromo para acompanhar o ensaio de posicionamento do "espetáculo tribal". Alguns dos integrantes da galera, atentos, faziam críticas ou teciam elogios ao que assistiam. Enumeravam as possibilidades diante da coreografia apresentada e do entrosamento dos dançarinos, o que poderia ou não dar certo. Um dos mais interessados era Cadu, extremamente crítico. Lá aconteceu também uma reunião prévia da galera com definição de posicionamento e outros detalhes.

A galera do Caprichoso está dividida em três facções, como indicado no esquema de sua distribuição nas arquibancadas do bumbódromo. A comunidade do Orkut chama atenção no entanto pelo papel importante que desempenha reconhecidamente com participação ativa de boa parte de seus 20 mil membros. Os que assistem e marcam presença no festival se dividem com funções na arena, na FAB ou independentemente. Um intrincado sistema de conflitos orienta a formação e organização de cada uma das três facções. Quem me explicou um pouco da formação desse sistema complexo que vigora atualmente foi o torcedor Rafael (depoimento em 21.6.2010), de 23 anos membro da comunidade do Caprichoso no Orkut e que revelou "nunca ter feito parte de nenhuma das facções":

$A$ FAB é a maior e mais organizada atualmente, mas surgiu de uma dissidência da FBI [Força Bravura e Independência]. A briga lá aconteceu por que a FBI era comandada ditatorialmente. Na nova administração do Caprichoso o presidente Carmona tentou unificar as duas na Raça Azul. A FBI perdeu força e acabou, mas a FAB, apesar de ter-se juntado à Raça Azul continuou existindo como FAB. Neste ano as duas estarão separadas.

As facções organizadas da galera são os centros irradiadores de todos os movimentos desse item durante as apresentações do boi. E comandam desde as coreografias, orientadas por quatro membros distribuídos em dois pequenos palanques na parte inferior da arquibancada, até a confecção de adereços e sua distribuição ao público durante as apresentações.

O núcleo manauara da FAB, por exemplo, aluga todos os anos uma casa em Parintins durante a semana do Festival em que ficam hospedados mais de 40 jovens dos 70 cadastrados na FAB-Manaus. A casa sempre movimentada é identificada com a bandeira do núcleo pendurada no muro frontal. Lá dentro uns dez cômodos abrigam os hóspedes distribuídos em redes, colchonetes, barracas e sacos de dormir. A cozinha, bastante organizada, é suficientemente espaçosa para 
acomodar o preparo de refeições em grandes quantidades. A comida é preparada por alguns pais dos jovens hospedados ou seus responsáveis, entre eles dona Fátima, mãe de Gean e presidente desse núcleo, que nos explicou que um grupo de adultos dirige e coordena a torcida, formada, entretanto, em sua maior parte por jovens. Essa direção que ressalta um aspecto bem familiar da organização se reflete, por exemplo, na presidência da FAB, hoje ocupada por Hyleandro, de 42 anos.

\section{OS ENSAIOS DA GALERA}

\section{Ensaio no curral}

Nessa noite o Garantido faria sua passagem de som no bumbódromo. Simultaneamente o Caprichoso realizaria seu último ensaio no curral. Um ensaio de fato! Com todas as tentativas e possibilidades testadas. Aqui uma apresentação semelhante a show é reservada para o final do ensaio. Era a oportunidade de se sentir na galera pela primeira vez. Gastar energias, vibrar e pular, como se o boi já se estivesse apresentando no bumbódromo. A coreografia é bem mais simples do que as executadas pela Troup Caprichoso²; ainda assim, as mais de duas horas ininterruptas de movimentos de braço e saltos são extremamente cansativas. O elemento mais evidente de diferenciação entre as coreografias complexas da Troup e as da galera é o uso significativo dos braços, com a finalidade de causar maior impacto visual na arquibancada durante as apresentações. As toadas, aliás, evocam a presença quase constante dos movimentos de braço:

braços erguidos, minha Galera / balançando pra lá e pra cá / eu sou a raça, sou a força da Galera / sou a voz, a garganta, o cantar ("Chegada do meu boi", de Adriano Aguiar).

Braços, bandeiras se movem / Num terno instante / O vento que sopra / Nos traz o encanto / Na força de ver a nossa paixão ("Amor e paixão", de Cyro Cabral).

Os braços tocam as estrelas / E livremente balanceiam / A voz do povo ecoa no ar há, há, há / O suor beija a camisa / Da raça azulada ("Apogeu Azul", de Mendes, Geandro Pantoja, Marcelo Reis e Junior Mendes).

Levanta Galera os braços para o ar / Balançando pra lá e pra cá / Na palma da mão / Quero ver você dançar / Na palma da mão / Quero ver você cantar ("Boi Estrela”, de Robson Jr, Marcelo Reis, Mailzon Mendes).

eu sou da raça, sou da Galera / Parintins está em festa e ninguém vai me segurar / minha Galera vem no compasso / nossas bandeiras são nossos braços ("Parintins em Festa II", de Adriano Aguiar, Geovane Bastos e Michael Trindade). 


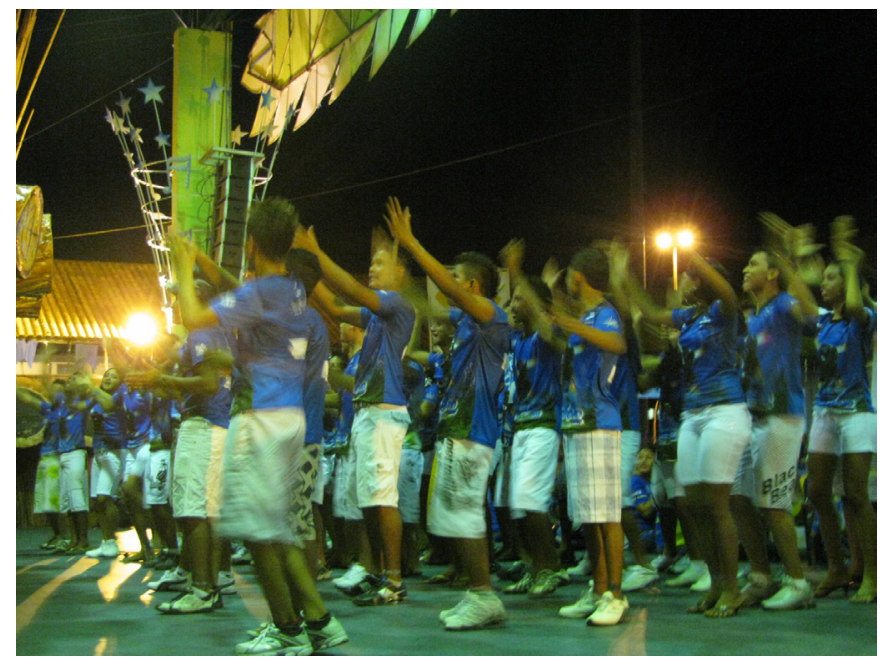

Figura 2: A galera de braços erguidos no ensaio, 2010 Foto do autor

E outros inúmeros casos recorrentes todos os anos comprovam essa predominância na coreografia com os braços. A Marujada de Guerra ${ }^{3}$, no entanto, é um incentivo a mais para a execução das coreografias e continuidade da empolgação da galera que, por esse motivo, ensaia no curral de frente para o palco, e a Marujada está localizada um pouco abaixo do palco, mas acima do nível da galera e do público. De frente para o público e situados em pequenos palanques no nível da Marujada ficam os coreógrafos da galera, que se revezam em duplas durante todo o ensaio. A posição de coreógrafo é semelhante a de um animador que usa apenas seu corpo na performance. Esse é posto bem disputado pelos jovens segundo alguns interlocutores. Sua ocupação resulta de arranjos políticos entre os dirigentes dos núcleos das facções das galeras, mas geralmente recai em homens de aptidão ou formação atlética, a maioria de Parintins, embora alguns sejam de Manaus (Figura 2).

A galera, posicionada de frente para o palco, é organizada em fileiras no centro do curral de forma a destacar-se do público geral. Inicialmente o grupo vestido com camisas da Raça Azul era maior nas primeiras fileiras; em pouco tempo, porém, a FAB já era maioria no grupo. Nas últimas fileiras e nas laterais ficam os mais jovens e as pessoas não uniformizadas. Todo o roteiro de toadas é acompanhado por esse grupo, enquanto o grande público revela ou indiferença por suas coreografias ou adesão às da Troup, localizada em grupos formados por meninos e meninas ao lado do palco principal. Em determinado momento os animadores abandonam a coordenação das coreografias e deixam o grupo organizado livre para acompanhar a complexa coreografia da Troup. Nesse momento o entusiasmo dos jovens é maior, e o ensaio torna-se mais livre, até para os cantores, 
que abandonam o roteiro musical programado para o Festival. Não há, entretanto, quebras ou intervalos até que a Marujada pare de tocar e o palco seja ocupado por um grupo musical que canta toadas do Caprichoso. Após a apresentação desse grupo, de cerca de duas horas, o ensaio é encerrado.

\section{Ensaio da Galera na passagem de som do bumbódromo}

$\mathrm{Na}$ arena pude assistir a uma reunião da FAB para a definição de alguns detalhes. A questão mais importante era a mobilização do pessoal para a montagem dos kits com adereços a ser usados na festa, distribuídos na entrada para as arquibancadas gratuitas pela FAB e Raça Azul. Essa montagem, envolta em mistérios, é em parte feita pelo pessoal da FAB no galpão, em parte pela Raça Azul no curral. Quem comandou essa reunião mais uma vez foi Hyleandro, que concedia alguns apartes para esclarecimento de detalhes à Fátima, mãe de Gean. Em torno dos dois em pé, próximos da entrada de serviço da arena já bastante movimentada nesse dia, estavam 30 jovens uniformizados da FAB. que não se manifestaram, apenas ouvindo as orientações, e vez por outra um ou outro se dispersava. Eles comemoraram logo a seguir o anúncio de uma festa no dia seguinte, quinta-feira, restrita aos jovens da FAB e com hora para começar e acabar, segundo Hyleandro, pois todos teriam que estar em condições de dar o máximo na sexta-feira. Após encerrar a reunião, Hyleandro saiu rapidamente e tentei conversar com Fátima, que dessa vez mostrou-se esquiva e desconfiada. Perguntei se poderia acompanhar a festa, e ela disse ser "melhor não, pois é uma pequena comemoração dos meninos, nada demais". Logo a seguir vetou também minha ida ao galpão para acompanhar a preparação dos kits, alegando que "acabaria rapidamente, provavelmente em poucas horas e na quinta e na sexta eles seriam apenas embalados".

À noite pudemos observar pela primeira vez a performance da galera nas arquibancadas da arena durante a passagem de som do Boi Caprichoso. Nesse evento seus membros ocupavam toda a arquibancada azul e uma parte do lado vermelho. Todos os integrantes executaram as coreografias e cantaram as toadas dos três dias de apresentação, com integrantes da chamadas tribos, vaqueiradas e, nas arquibancadas, a galera. Com grandes bandeiras e uniformizados, sua atuação parecia a das torcidas organizadas nos estádios de futebol: um pequeno núcleo uniformizado executava coreografias e incentivava o público a acompanhálo. No início ainda conseguiu boa adesão, mas 40 minutos depois o público começou a dispersar, até invadindo a arena. Em determinado momento, já perto do fim da apresentação apenas o núcleo uniformizado permanecia executando coreografias na arquibancada. A passagem de som foi, portanto, mais uma festa de confraternização e apoteose do que um ensaio (Figura 3). 


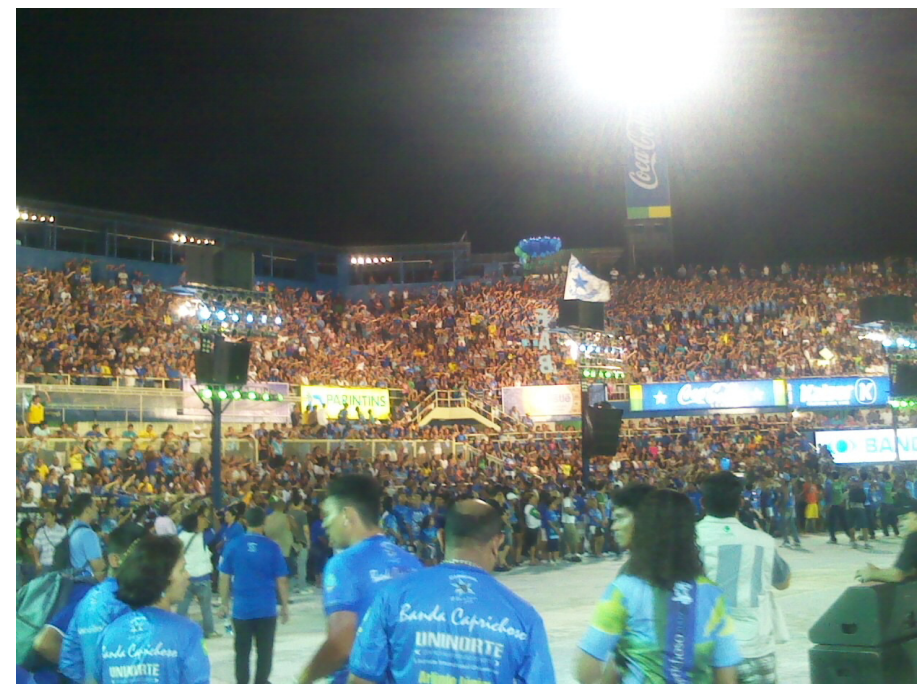

Figura 3: A galera durante a passagem de som na Arena, 2010 Foto do autor

No dia seguinte participei da reunião do pessoal da FAB com integrantes da comunidade do Caprichoso. A reunião novamente foi comandada por Hyleandro, que antevia uma importante contribuição dos membros da comunidade do Caprichoso para organização da galera nas arquibancadas. Segundo suas palavras, a intenção era reverter dois anos de "galera fraca". Curioso é que, mesmo sendo título simbólico, é importante a ponto de ser anunciado antes da declaração oficial do campeão do festival; e, há pelo menos nove anos, a galera do Caprichoso perde para a do Garantido. Os participantes da reunião logo reclamaram, culpando os coreógrafos de Parintins que segundo eles são muito confusos.

De qualquer forma a reunião servia também para informar mudanças repentinas no roteiro de apresentação do boi no primeiro dia de festival. Segundo Hyleandro, o roteiro das três noites do Caprichoso havia vazado, fazendo com que o Garantido mudasse também suas apresentações de acordo com a do Caprichoso. Outra informação dizia respeito à presença de Daniela Mercury para a abertura da primeira noite do Garantido: ela cantaria o hino nacional, a galera formaria um mosaico de velas e de retângulos de tecido nas cores da bandeira brasileira. As outras duas manifestações ativas e impactantes da galera foram apresentadas, e um ousado e complicado deslocamento pelas arquibancadas foi testado.

Hyleandro recomendava chegar às 10 horas da manhã na fila, embora a abertura dos portões estivesse prevista para 16 horas, e o início das apresentações às 21 horas. A questão da ocupação de lugares é componente direto na decisão da chegada na fila, e a disputa por lugares dá uma dimensão da festa; afinal, naquele espaço da galera, são 3.750 pessoas. 


\section{Os dias de festival}

Enfim, é chegada a hora de a batalha começar, especialmente a batalha por lugares dentro do bumbódromo.

A fila funciona como espaço profícuo para desenvolvimento de diversas redes de sociabilidade. Ela reúne diversas pessoas de diferentes classes sociais que, em decorrência da relação estabelecida na fila, ocupam lugares próximos na arquibancada e, pelo fato de o festival se estender por três dias, combinam encontros nas próximas filas.

Cheguei na fila pouco antes das 10 horas da manhã e logo me enturmei com Júnior, funcionário da manutenção do prédio da Câmara Municipal de Manaus, que estava na minha frente e era o quarto da fila do Caprichoso. Na fila do Garantido parecia haver um número maior de pessoas; afinal de contas, seria o primeiro grupo a se apresentar naquela noite. O primeiro da fila era Rubens de aproximadamente 50 anos, conhecido por seu nome artístico nos shows de dragqueens de Manaus, Rubileia, e reconhecido pelos torcedores também por suas recorrentes aparições na televisão, instalado nas arquibancadas durante o Festival. Ele me revelou que fazia questão de chegar antes das 7 horas da manhã para garantir um lugar de frente para a câmera posicionada no alto da arquibancada. Por outro lado, Junior buscava melhor visão das apresentações. Pouco depois de minha chegada na fila começou a chover. As pessoas se abrigavam com caixas de papelão logo destruídas, dividindo capas de chuva ou nos bares próximos. Havia na fila quem apenas guardava lugar para outros, que chegariam posteriormente. Pareciam ser amigos, sem negociação de lugares na fila que pude observar no segundo dia o morador de Parintins Raimundo que disse viver de "bicos", por exemplo, levou seus cinco filhos e três sobrinhos para guardar lugares que ele vendera previamente. Cobrava 20 reais por lugar, mas se "sentisse que o sujeito estava desesperado cobraria 50 reais". Não satisfeito em ocupar um dos primeiros lugares vez por outra os que estavam na fila chamavam atenção para tentativas de Raimundo de "furar fila".

As conversas entre os recém-conhecidos na fila são as mais variadas, e nas mais de seis horas de cada um dos dias de fila que acompanhei ouvi desde palpites sobre minha vida amorosa até o cenário político do Amazonas. O tema predominante, entretanto, obviamente é a apresentação dos bois. Os torcedores se deliciam com as recordações de outros festivais ou falando mal do "contrário". As expectativas e especulações sobre a apresentação do Caprichoso entusiasmam e são sempre otimistas, seguidas da constatação das deficiências do contrário.

Na parte da tarde, com a fila já circundando quase toda a arena, a diversão dos que aguardam a abertura dos portões é vaiar e jogar objetos nos que insis- 
tem em passar de vermelho ou com a camisa do Garantido. Segundo Júnior, um dos motivos para a proibição da entrada nas arquibancadas com frutas é sua utilização como arma; "era comum", ele observou, "guardar cascas e caroços para jogar nos contrários dos camarotes que provocassem ou no pessoal deles que passa na frente da fila e na passagem de som".

Pouco antes das 14 horas a expectativa aumenta com a montagem das barreiras para organização de duas filas que facilitem a revista da polícia militar. Começam também as discussões sobre os lugares na fila e reclamações da demora da abertura dos portões. Finalmente às 16 horas os portões são abertos. Quando as pessoas passam pela revista começam a correr buscando subir a rampa o mais rápido possível e chegar logo nas arquibancadas; antes disso, porém, passam por outra barreira formada por membros da FAB e Raça Azul que entregam os kits com os adereços usados na noite de apresentação (Figura 8). Finalmente acomodados na arquibancada do bumbódromo, basta esperar a noite chegar.

O período de permanência nas arquibancadas antes das apresentações dos bois é revestido de grande ansiedade. Mesmo em números reduzidos as galeras permanecem agitadas cantando toadas de desafio ou gritando provocações e xingamentos ao "contrário". O público enche inicialmente o pedaço com sombra da arquibancada azul, mais próximo do centro da arena.

Por volta de 17 horas com as arquibancadas completamente tomadas, começa a passagem de som do primeiro boi a se apresentar. No primeiro dia foi o Garantido que levaria Daniela Mercury, famosa cantora baiana, para abrir o Festival. Ela apareceu para a passagem de som, que foi aberta com provocações do apresentador Israel Paulain exclamando "Xô Urubu" em referência ao touro negro que representa o Caprichoso. Esse é o momento em que as provocações são abertas e permitidas na arena. A galera do Caprichoso obrigada a permanecer calada durante a apresentação do contrário pelo regulamento iria rebater assim que a cantora Daniela Mercury começasse a cantar com um uníssono "É Timbalada!". O fato de o Garantido levar uma cantora de fora do Amazonas era visto como desprestígio pelos brincantes do Caprichoso. Cada passagem de som dura aproximadamente 40 minutos. Na passagem de som do Caprichoso algumas das coreografias e ações da galera foram combinadas publicamente pelo microfone através do amo do boi Edilson Santana, que pediu a participação do público gritando pouco antes do anúncio do levantador de toadas David Assayag. Entre a execução de uma toada e outra, David respondia às provocações feitas pouco antes pelos integrantes do Garantido com novas provocações. A passagem de som do segundo dia, por exemplo, foi encerrada com uma toada de desafio feita pelo próprio David. 
No primeiro dia de apresentações o Garantido foi o primeiro a se apresentar, e, a cada erro seu, como quando sua cunhã-poranga caiu, uma euforia contida era revelada no lado azul, que deveria, em obediência ao regulamento, permanecer calado durante toda a apresentação. No primeiro dia o Garantido ainda estourou o tempo, e nesse momento quase que um grupo se manifesta com satisfação pela desgraça do contrário.

A apresentação do Caprichoso começou com movimentos de braços para o alto incentivados pelo apresentador Júnior Paulain cantando a toada "Sentimento Caprichoso" e ressaltando que "esse seria o diferencial, nossas bandeiras serão nossos braços". Logo a seguir o amo do boi apresentou o levantador de toadas, e, aos primeiros toques da Marujada, o público pulava em frenesi enlouquecedor, sendo difícil para quem está perto não se emocionar. A participação dos núcleos uniformizados é fundamental nesse momento, pois um espaço é criado no limite entre as duas facções, que se vão unindo de acordo com os versos da toada.

Em todos os dias de apresentação os centros de irradiação das coreografias e das formas de utilização dos adereços, que podem surgir arremessados do alto da arquibancada por um membro uniformizado da FAB, eram os dançarinos em palcos posicionados de costas para a arena e de frente para a arquibancada da galera. Ocasionalmente Hyleandro percorria a arquibancada com um megafone dando instruções ao público. No primeiro dia especialmente ele reforçou várias vezes os pedidos para que as cordas que delimitavam uma bandeira do Brasil a ser formada com quadrados de tecido não fossem desatadas pelo público. No segundo dia de apresentações pude constatar que alguns dos membros da FAB circulam credenciados pela arquibancada, verificando se alguma irregularidade estava sendo cometida, como, por exemplo, um torcedor do Garantido à paisana infiltrado na arquibancada. Parece que não é raro a arquibancada do rival do boi que se apresenta em primeiro lugar receber alguns torcedores não identificados do contrário.

No terceiro dia as pirotecnias, como a luz de candeais, e grandes botos apelam para o impacto visual que, após dois dias de apresentação, pode aliviar possível cansaço da galera, nem por isso, entretanto, menos emocionada do que nas apresentações precedentes.

\section{APURAÇÃO E A FESTA DO BOI VENCEDOR}

Encerrado o festival a apuração reserva emoções ainda mais inusitadas; ela acontece no bumbódromo e é cercada de tensões. Chegamos um pouco antes do horário programado, mas até isso é cercado de mistérios. Antes do festival não 
conseguíamos informação exata sobre o horário da apuração, tampouco sobre o local de sua realização. Durante o festival continuamos tentando, mas sem sucesso; só na madrugada do último dia de apresentações Alessandro mandou uma mensagem de texto pelo celular informando que aconteceria às 10 horas da manhã seguinte no bumbódromo. No dia de fato da apuração a arena estava completamente vazia o que nos causou estranheza. Procuramos nos informar com alguns funcionários que nos indicaram uma entrada entre o centro da arena e a entrada da galera do Garantido. Por lá torcedores com camisa do Garantido em torno de duas dezenas aguardavam o inicio da apuração. Já combalido da maratona das três noites, mesmo febril resistiu de pé durante as quase duas horas de atraso do inicio da mesma. No primeiro anúncio pelo sistema de som de que a apuração começaria em 30 minutos nos dirigimos para as arquibancadas da galera do Caprichoso. Lá encontramos três meninos da Marujada já aguardando a apuração. O sol sobre quase a totalidade da arena pode ser uma explicação para a ausência de público naquele momento. Quando o sistema de som anunciou que faltavam cinco minutos para o início da apuração muitos torcedores começaram a ocupar as arquibancadas da arena, ainda que timidamente. A apuração começa com o anúncio da impugnação das notas dos jurados de Tocantins, que pediram para sair do júri. Curiosamente os torcedores dos dois bois comemoraram a notícia. Do lado do Caprichoso um torcedor explicava a comemoração: "Devem ter sido comprados pelo Garantido. Eles sempre fazem isso". Posteriormente os jornais anunciaram que a razão para a saída de parte do júri seria pressão dos fiscais do Garantido por suspeitas de ligação do presidente do júri com o Caprichoso.

Quando a apuração começa as arquibancadas contam com a presença de algumas dezenas de torcedores dos dois lados. Um cordão de isolamento do Batalhão de Choque da Polícia Militar divide a arena. À medida que as notas são anunciadas ofensas são trocadas, e conforme um dos bois vai tomando a dianteira o seu lado da arena vai recebendo mais público. As provocações vão aumentando. Em determinado momento uma nota 8 para o Garantido foi o suficiente para que alguns torcedores descessem das arquibancadas para dançar perto dos policiais. A distância entre os pontos dos dois bois foi aumentado, chegando, ao final da apuração, a 10,2, considerada grande no histórico do festival. Enquanto alguns comemoravam se abraçando e entoando cânticos de provocação ao rival, outros, mais tensos, esperam a confirmação do resultado oficial pelo sistema de som. Antes do anúncio do campeão, houve a da galera vencedora, do Garantido, o que provocou breve comemoração no lado vermelho da arena. Logo a seguir o campeão foi anunciado, iniciando-se uma sequência alucinada de regozijos na arquibancada azul, que segue em caminhada até seu curral (Figura 4). 


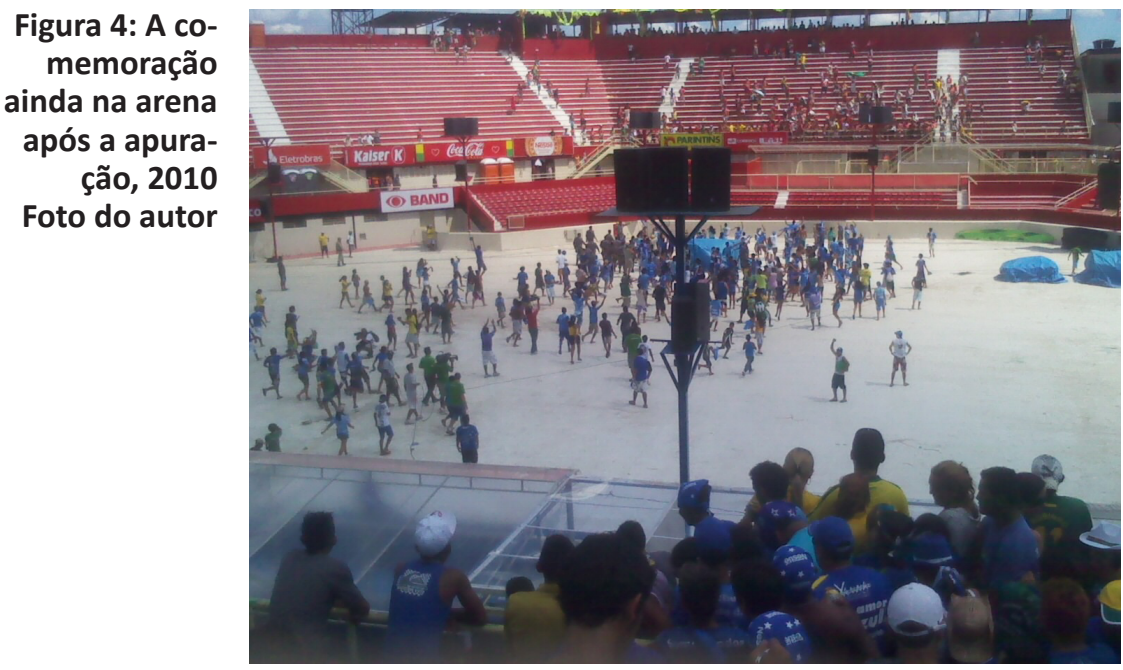

Em cena inusitada, o antropólogo, despido de todo o seu pudor e distanciamento científico, solta impropérios dos mais diversos junto à turba que se agita. A cena é mais surpreendente ainda se imaginarmos que quilômetros de distância separam o antropólogo da residência dos envolvidos na arena de agressões mútuas. É mais estranho ainda imaginar que todo o vocabulário de impropérios traz em seu conteúdo uma série de palavras e símbolos evocados apenas por quem se acostumou com aquele universo cosmológico e só fazem sentido para os que compartilham daquele universo. Regozijar-se de uma vitória em um universo ritual tão complexo, em tão pouco tempo de convivência nos leva a uma série de reflexões sobre essa festa, esse ritual que todos os anos acontece na llha Tupinambarana.

\section{REFERÊNCIAS BIBLIOGRÁFICAS}

CÂMARA, Rosana da. Torcidas jovens: paixão, amizade e aventura. In: ALVIM, Rosilene; GOUVEIA, Patricia (orgs.). Juventude nos anos 90. Rio de Janeiro: Contra Capa Livraria, 2000.

CAVALCANTI, Maria Laura. As grandes festas. In SOUZA, Márcio de; WEFFORT, Francisco (orgs.). Um olhar sobre a cultura brasileira. Rio de Janeiro: Funarte/Ministério da Cultura, p. 293-311, 1998.

. O boi-bumbá de Parintins, Amazonas: breve história e etnografia da festa. História, Ciência e Saúde - Manguinhos, v. 6 (suplemento), p. 10191046. Rio de Janeiro: Fiocruz, 2000.

. The Amazonian Ox Dance Festival: An Anthropological Account. Cultural Analysis, 2, p. 69-105. The University of California. 2001. 
. Os sentidos no espetáculo. Revista de Antropologia. São Paulo,v. 45, n. 1, p. 37-80. 2002.

CECHETTO, Fátima. As galeras funk cariocas: entre o lúdico e o violento. In: VIANA, Hermano (org.). Galeras cariocas: territórios de conflitos e encontros culturais. Rio de Janeiro: Editora UFRJ, 1997.

\section{NOTAS}

10 Caprichoso realiza evento da mesma natureza no mesmo local chamado Bar do Boi.

2 Um núcleo de dançarinos do Corpo de Dança do Caprichoso que executa os passos específicos de cada toada no palco dos ensaios do Boi. São uma espécie de referência para o público que dança conforme a coreografia por eles executada.

3 Marujada de Guerra é o grupo rítmico do Boi Caprichoso.

Ricardo José Barbieri é doutorando do Programa de Pós-Graduação em sociologia e antropologia da UFRJ.

Recebido em: 10/12/2011

Aceito em: 28/02/2012 